\title{
PENGARUH MODEL PEMBELAJARAN TAI (TEAM ASSISTED INDIVIDUALIZATION) TERHADAP HASIL BELAJAR SISWA
}

\author{
Moh. Halih \\ (Pendidikan Matematika, Fakultas Keguruan dan Ilmu Pendidikan, Universitas PGRI Adi Buana Surabaya) \\ mohamadhalih@gmail.com
}

\begin{abstract}
The research was done because there were a lot of students who have minimum score in mathematic subject. The statement of the problem is "Is there any influence in TAI teaching model to the students' achievement?". The purpose of this study is to know the influence of TAI teaching model to the students' mathematic achievement. TAI teaching model is one of the model in teaching which focuses on group, the students were divided in some small group in a class, member of group were consists of 4-5 students in a group. Then in this research the students were given "Himpunan"material. The sample of this research consists of two classes, the first is experiment class with 33 students who were given TAI teaching model, then the second is control class with 33 students who were given conventional teaching model. To know and analyze the students' achievements, the researcher used posttest for both two classes. Based on the research conducted at SMP Rahmat Surabaya. The researcher concluded that the result of using TAI teaching model was given significant change the students score of experiment class, than using conventional teaching model in control class. After the students are given "Himpunan" material, they are given a posttest for the data analysis. The writer uses t-test for the data analysis. The research result is $\mathrm{t}_{\text {count }}<\mathrm{t}_{\text {table }}$ $(3,45>1,998)$. So it could be conclude that TAI teaching model influenced on the students' mathematic achievement for the seventh grade students on SMP Rahmat Surabaya.
\end{abstract}

Keywords: TAI teaching model, students' achievement.

\section{PENDAHULUAN}

Pendidikan merupakan jembatan emas untuk menuju kesuksesan. Melalui pendidikan, diharapkan mampu mewujudkan peningkatan kualitas Sumber Daya Manusia demi mendukung kelangsungan pembangunan nasional, khususnya dalam menghadapi era persaingan global.

Keberhasilan pendidikan tercermin dalam proses belajar dan hasil belajar. Dengan demikian untuk meraih hasil belajar yang optimal, dibutuhkan relasi dari seluruh komponen pendidikanmeliputi siswa, guru, kurikulum dan sarana penunjang pendidikan. Siswa merupakan komponen utama dibanding yang lain, sebab siswa merupakan sasaran utama yang akan dibimbing untuk menjadi manusia berkualitas, tangguh dalam menghadapi era globalisasi. Selain itu siswa merupakan tolok ukur keberhasilan pendidikan itu sendiri.

Berdasarkan observasi yang telah dilakukan di SMP Rahmat Surabaya sebelum penelitian diketahui bahwa peserta didik belum mampu mencapai standar yang diinginkan, ini terlihat dari nilai ulangan harian siswa yang masih banyak

mendapatkan nilai matematika dibawah KKM yang telah ditetapkan oleh satuan pendidikan. Hal ini disebabkan karena terjadinya kelas yang cenderung teacher centered dengan menggunakan pembelajaran konvensional sehingga peserta didik menjadi pasif. Meskipun demikian, sebagian guru menerapkan model pembelajaran tersebut karena tidak begitu merepotkan yakni tidak mengeluarkan banyak biaya dan media pembelajaran. Padahal secara tidak langsung hal ini dapat mengakibatkan kebosanan pada peserta didik dan kesulitan dalam memahami materi terutama pada pelajaran matematika. Untuk mengatasi hal tersebut dibutuhkan model pembelajaran yang dapat menarik minat siswa.

Salah satu model pembelajaran kooperatif yang sangat menarik adalah tipe TAI (Team Assisted Individualization). Pada umumnya model pembelajaran kooperatif didasari falsafah homo homini socius yang menekankan bahwa manusia adalah makhluk sosial dan membutuhkan kerja sama (Lie, 2010 : 28). Namun tipe TAI memiliki keunikan 
khusus karena menerapkan gabungan belajar dari masing - masing individu dan secara berkelompok.

Dalam model pembelajaran TAI, siswa dibagi menjadi menjadi kelompok kecil dengan pembagian secara random dan disertai pemberian motivasi secara individu baik berupa dukungan moral, sosial, fungsional bagi siswa yang membutuhkan.

Rumusan masalah dalam penelitian ini adalah "Apakah ada pengaruh model pembelajaran TAI (Team Assisted Individualization) terhadap hasil belajar siswa SMP Rahmat tahun pelajaran 2015/2016?"

Berdasarkan pemaparan diatas, maka penulis mengadakan penelitian dengan judul "Pengaruh Model Pembelajaran TAI (Team Assisted Individualization) Terhadap Hasil Belajar Siswa”.

\section{METODE PENELITIAN}

Penelitian ini merupakan penelitian kuantitatif dengan menggunakan jenis posttest only group design yang menjelaskan bahwa ada dua kelas penelitian yang diberi treatment (perlakuan) berbeda. Dimana kelas eksperimen diberi perlakukan berupa pembelajaran dengan menggunakan model pembelajaran TAI (Team Assisted Individualization) dan kelas kontrol diberi perlakuan berupa pembelajaran langsung. Selanjutnya setelah penelitian selesai, baik kelas eksperimen maupun pada kelas kontrol diberikan tes untuk mengetahui hasil belajarnya.

Metode pengumpulan data pada penelitian ini menggunakan metode tes. Penelitian ini dilaksanakan di SMP Rahmat Surabaya, dengan populasi seluruh siswa kelas VII SMP Rahmat Surabaya. Pengambilan sampel pada penelitian ini menggunakan teknik non probability sampling dengan metode accidental sampling yakni pengambilan sampel didasarkan pada kenyataan bahwa hanya sampel itulah yang tersedia untuk diteliti. Sampel diambil berdasarkan kelas yang telah diberikan sekolah kepada peneliti kemudian dijadikan kelompok kontrol dan kelompok eksperimen. Kelas VII A sebagai kelompok eksperimen sebanyak 33 siswa dan kelas VII B sebagai kelas kontrol sebanyak 33 siswa.

Data yang diperoleh dari hasil penelitian ini untuk selanjutnya dianalisis. Analisis yang digunakan adalah analisis ketuntasan hasil belajar siswa dan analisis rata-rata. Adapun langkahlangkah analisis ketuntasan belajar siswa adalah sebagai berikut:

1. Data tes yang dihasilkan setelah proses pembelajaran dianalisis untuk mendeskripsikan ketuntasan hasil belajar siswa. Standar ketuntasan untuk mata pelajaran matematika yang digunakan di SMP Rahmat Surabaya adalah sebagai berikut:

a. $\quad$ Siswa dikatakan tuntas (T), jika skor $\geq 75$ : Tuntas (T)

b. Siswa dikatakan tidak tuntas (TT), jika skor $<$ 75: Tidak Tuntas (TT)

2. Kemudian dari data ketuntasan belajar siswa tersebut dihitung presentase ketuntasan belajar secara klasikal. Bila $\geq 85 \%$ siswa dalam kelas tersebut tuntas, maka ketuntasan belajar dapat dikatakan tercapai. Perhitungan untuk menyatakan presentase banyaknya siswa yang tuntas adalah dengan menggunakan rumus:

$$
P=\frac{A}{B} \times 100 \%
$$

Keterangan:

$\mathrm{P} \quad=$ Presentase siswa yang tuntas

A = Jumlah siswa yang tuntas

B = Jumlah siswa dalam kelas

Setelah diadakannya analisis ketuntasan belajar siswa, data digunakan untuk dianalisis nnilai ratarata kelas eksperimen dan kelas control. Peneliti melakukan penjumlahan nilai yang diperoleh siswa, yang selanjutnya dibagi dengan jumlah siswa yang 
ada di kelas tersebut sehingga diperoleh rata-rata tes formatif dapat dirumuskan:

$$
\bar{X}=\frac{\sum X}{N}
$$

Dengan $: \bar{X}=$ Nilai rata-rata

$$
\begin{aligned}
& \sum X=\text { Jumlah semua nilai siswa } \\
& \mathrm{N}=\text { Jumlah siswa }
\end{aligned}
$$

Hasil analisis data pada penelitian ini digunakan untuk pengujian hipotesis. Sebelum pengujian ada tiga uji yang harus dilakukan yaitu uji normalitas, uji homogenitas, dan uji t. Adapun langkah-langkah uji normalitas adalah sebegai berikut:

\section{Merumuskan Hipotesis}

Ho : Data berdistribusi normal

Ha : Data tidak berdistribusi normal

2. Menyusun data dan mencari nilai tertinggi dan terendah.

3. Membuat interval kelas dan menentukan batas kelas.

4. Menentukan jangkauan / rentang,

Jangkauan $=$ nilai tertinggi - nilai terendah

5. Menentukan banyak kelas

Banyak kelas $=1+3,3 \log n$

6. Menentukan panjang kelas

Panjang kelas = jangkauan $:$ banyak kelas

7. Menghitung rata-rata

$$
\bar{X}=\frac{\sum f_{i} x_{i}}{\sum f_{i}}
$$

8. Menghitung simpangan baku

$$
=\sqrt{\frac{\sum f_{i} x_{i}^{2}}{n}-\left(\frac{\sum f_{i} x_{i}}{n}\right)^{2}}
$$

9. Menentukan nilai uji statistika

$$
\left(X_{\text {hitung }}\right)^{2}=\sum\left(\frac{\left(f_{o}-f_{h}\right)^{2}}{f_{h}}\right)
$$

10. Menentukan derajat kebebasan dan taraf nyata

11. Menentukan kriteria pengujian

$\mathrm{H}_{0}$ ditolak jika $X_{\text {hitung }}^{2} \geq X_{\text {tabel }}^{2}$
$\mathrm{H}_{0}$ diterima jika $X_{\text {hitung }}^{2}<X_{\text {tabel }}^{2}$

12. Menarik kesimpulan

Jika Ho ditolak maka data berdistribusi normal dan data dapat dilanjutkan ke uji homogenitas, tetapi apabila sebaliknya H0 diterima maka data tidak berdistribusi normal. Salah satu cara yang dapat dilakukan jika data tidak berdistribusi normal adalah menambah jumlah sampel.

Jika data telah berdistribusi normal dilanjutkan ke uji homogenitas varians data skor posttest. Pengujian varians antara kelompok eksperimen dan kontrol dilakukan untuk mengetahui apakah kedua kelompok tersebut memiliki variansi yang homogen atau tidak homogen. Adapun langkahnya adalah sebagai berikut:

1. Merumuskan formula hipotesis

Ho : Data bersifat homogen

Ha : Data tidak bersifat homogen

2. Menentukan varians

$$
S D^{2}=\frac{\sum X_{1}^{2}-\frac{\left(\sum X_{1}\right)^{2}}{N}}{N-1}
$$

3. Menentukan uji statistika

$$
F=\frac{\text { Varian terbesar }}{\text { Varian terkecil }}
$$

4. Menentukan taraf nyata $(\alpha)$ dan $F_{\text {tabel }}$ $F_{\text {tabel }}$ ditentukan dengan $\alpha$ dan derajat kebebasan (dk) pembilang (jumlah data varian terbesar - 1) dan derajat kebebasan penyebut (jumlah data varian terkecil - 1).

5. Menentukan kriteria pengujian:

Ho ditolak jika $F_{\text {hitung }} \geq F_{\text {tabel }}$

Ho diterima jika $F_{\text {hitung }}<F_{\text {tabel }}$

6. Menarik kesimpulan dengan ini jika Ho diterima maka kedua data bersifat homogen. Apabila Ho ditolak yang artinya kedua data tidak homogen, yang dapat dilakukan adalah menyusun ulang kedua sampel. 
Setelah uji normalitas dan uji homogenitas, data digunakan untuk pengujian hipotesis. Dari pengujian hipotesis dapat ditarik kesimpulan. Adapun langkah-langkah pengujian hipotesis sebagai berikut:

1. Menentukan hipotesis yang digunakan adalah:

$$
\begin{aligned}
& \mathrm{H}_{0}=\mu_{1}=\mu_{2} \\
& \mathrm{H}_{1}=\mu_{1} \neq \mu_{2}
\end{aligned}
$$

Keterangan:

$\mu_{1}=$ Rata-rata kelompok eksperimen

$\mu_{2}=$ Rata-rata kelompok control

Ho : $\mu_{1}=\mu_{2}$. (Tidak ada pengaruh model pembelajaran TAI terhadap hasil belajar pada siswa kelas VII A SMP Rahmat Surabaya)

$\mathrm{H}_{1}: \mu_{1} \neq \mu_{2}$. (Ada pengaruh model pembelajaran

TAI terhadap hasil belajarpada siswa kelas VII A SMP Rahmat Surabaya.).

2. Menentukan tingkat kepercayaan / signifikan : $\alpha$ $=5 \%$.

3. Menentukan uji statistik :

$$
t=\frac{\bar{X}_{1}-\bar{X}_{2}}{s \sqrt{\frac{1}{n_{1}}+\frac{1}{n_{2}}}}
$$

Dimana:

$$
s=\sqrt{\frac{\left(n_{1}-1\right) S_{1}^{2}+\left(n_{2}-1\right) S_{2}^{2}}{n_{1}+n_{2}-2}}
$$

Melakukan kriteria pengujian $\mathrm{H}_{0}$ diterima jika menggunakan $\alpha=5 \%$ menghasilkan $t_{\text {hitung }} \leq t_{\text {tabel }}$ dengan $d k=n_{1}+n_{2}-2$ dan $\mathrm{H}_{0}$ ditolak untuk harga $t$ lainnya.

4. Menentukan kriteria pengujian

$$
\begin{aligned}
& \text { Ho diterima jika : } t_{(1-1 / 2 \alpha)} \leq t \leq t_{(1-1 / 2 \alpha)} \\
& \text { Ho ditolak jika : } t_{(1-1 / 2 \alpha)} t<t_{(1-1 / 2 \alpha)}
\end{aligned}
$$



Gambar kriteria penerimaan $\mathrm{H}_{\mathrm{o}}$

\section{Menarik kesimpulan}

Kesimpulan ditarik berdasarkan perhitungan yang diperoleh dengan rumus statistika yaitu apakah Ho ditolak atau diterima.

\section{HASIL DAN PEMBAHASAN}

Hasil penelitian ini disajikan dengan uji hipotesis. Pengujian hipotesis ini dilakukan untuk mengetahui adanya perbedaan model pembelajaran TAI (Team Assisted Individualization) dan pembelajaran konvensional terhadap hasil belajar matematika didasarkan pada hasil analisis uji t.

Hipotesis yang digunakan adalah Ho yaitu tidak ada pengaruh antara hasil belajar siswa dengan model pembelajaran TAI (Team Assisted Individualization) terhadap hasil belajar siswa, didukung dengan taraf signifikansi 5\%, maka $t_{\text {tabel }}=$ 1,998. Dengan perhitungan uji $\mathrm{t}$ diperoleh $\mathrm{t}_{\text {hitung }}=$ 3,45 , dengan begitu $t_{\text {hitung }}$ terletak pada daerah penolakan Ho. Dari pengujian hipotesa yang telah dilakukan maka Ho ditolak dan $\mathrm{H}_{1}$ diterima yang artinya ada perbedaan antara hasil belajar siswa dengan model pembelajaran TAI (Team Assisted Individualization) dan model pembelajaran konvensional terhadap hasil belajar siswa

Berdasarkan analisis data diatas dapat diketahui bahwa ada perbedaan hasil belajar antara kelas eksperimen dengan kelas kontrol. Perbedaan ini ditunjukan dengan nilai $\mathrm{t}_{\text {hitung }}=3,45>\mathrm{t}_{\text {tabel }}=1,998$ dengan taraf signifikansi 5\%. Dengan demikian dapat disimpulkan bahwa ada pengaruh model 
pembelajaran TAI (Team Assisted

Individualization) terhadap hasil belajar matematika dengan materi himpunan pada siswa kelas VII SMP Rahmat Surabaya.

Pengaruh model pembelajaran TAI (Team Assisted Individualization) ini juga dapat dilihat dari nilai rata-rata post test kelas eksperimen dengan kelas kontrol. Rata-rata kelas eksperimen lebih besar dibandingkan dengan rata-rata kelas kontrol. Selain itu dari analisis ketuntasan siswa, kelas eksperimen lebih banyak yang nilainya diatas KKM. Dengan demikian model pembelajaran TAI (Team Assisted Individualization) saat pembelajaran matematika memberikan dampak positif yaitu meningkatkan hasil belajar matematika siswa.

Selain itu siswa juga lebih aktif dalam kelas dan kemampuan siswa perlahan merata karena adanya kegiatan berkelompok dalam menyelesaikan permasalahan yang diberikan oleh guru.

\section{PENUTUP}

\section{Simpulan}

Berdasarkan penelitian diatas, dapat diperoleh kesimpulan bahwa terdapat pengaruh hasil belajar matematika dengan model pembelajaran TAI (Team Assisted Individualization) terhadap hasil belajar siswa di SMP Rahmat Surabaya tahun pelajaran 2015/2016. Siswa yang diberi model pembelajaran TAI (Team Assisted Individualization) memiliki nilai rata-rata yang lebih tinggi daripada model pembelajaran konvensional.

\section{Saran}

Berdasarkan temuan penelitian ini, penulis menyarankan sebagai berikut:

1. Untuk meningkatkan hasil belajar siswa dapat dipilih model pembelajaran Team Assisted Individualization, sebab berdasarkan penelitian ini telah terbukti bahwa kemampuan memecahkan masalah dalam pembelajaran model Team Assisted Individualization tersebut mempunyai pengaruh positif terhadap nilai hasil belajar siswa baik secara individu maupun kelompok.

2. Penggunaan model pembelajaran Team Assisted Individualization sebagai upaya untuk memaksimalkan hasil belajar siswa hendaknya disesuaikan dengan materi pelajaran dan kondisi kelas, mengingat penerapan pembelajaran tersebut belum tentu cocok untuk diterapkan pada semua materi pelajaran matematika dan pada semua kelas.

3. Dalam melaksanakan kegiatan belajar mengajar model pembelajaran Team Assisted Individualization hendaknya guru berperan sebagai fasilitator yang melibatkan siswa secara maksimal. Bentuk pelibatan siswa yaitu kerja sama antar teman untuk dapat memecahkan soal - soal pemecahan masalah, siswa dibimbing untuk bisa menemukan solusi pemecahan masalah secara berkelompok.

\section{DAFTAR PUSTAKA}

Arikunto, Suharsimi. 2013.Prosedur Penelitian Suatu Pendekatan Praktik. Jakarta : Rineka Cipta.

Aunurrahman. 2009. Belajar dan Pembelajaran. Bandung: Alfabeta.

Huda, Miftahul. 2013. Model-Model Pengajaran Dan Pembelajaran. Yogyakarta : Pustakan Pelajar

Johnson, D., Johnson, R. dan Holubec, Edythe. 2010. Colaborativ Learning Strategi Pembelajaran Untuk Sukses Bersama. Bandung : Nusa Media.

Lie, Anita. 2010. Cooperative Learning. Jakarta : Grasindo.

Merudewi, G.A Kencana, dkk. 2014. Pengaruh Model Pembelajaran Kooperatif Tipe Team Assisted Individualization Berbasis 
Moh. Halih : Pengaruh Model Pembelajaran Tai (Team Assisted Individualization) Terhadap Hasil Belajar Siswa

Peta Konsep Terhadap Hasil Belajar IPS

Siswa Kelas V SD Gugus Sukawati.

Diakses Pada Tanggal 17 Agustus 2015

Dari

http://digilib.uinsuka.ac.id/11310/1/BAB

$\% 20 \mathrm{I}, \% 20 \mathrm{~V}, \% 20 \mathrm{DAFTAR} \% 20 \mathrm{PUSTAK}$

A.pdf

Nasution, S. 2006. Berbagai Pendekatan dalam

Proses Belajar Mengajar. Jakarta : Bumi Aksara.

Runtukahu, Tombokan, dan Kandou, Selpius. 2014.

$P$ embelajaran Matematika Dasar bagi Anak Berkesulitan Belajar. Yogyakarta :

CV Arruzz Media.

Sanjaya, Wina. 2014. Strategi Pembelajaran.

Berorientasi Proses Pendidikan.

Yogyakarta : Kencana Prenada Media

Group.
Slavin, Robert. 2015. Cooperative Learning: Teori, Riset \& Praktik. Bandung : Nusa Media.

Sugiyono. 2010. Metode Penelitian Pendidikan. Bandung: Alfabeta

Sugiyono. 2014. Metode Penelitian Kuantitatif, Kualitatif dan $R \& D$. Bandung : CV. Alfabeta.

Widoyoko, Eko. 2011. Evaluasi Program Pembelajaran. Yogyakarta : Pustaka Pelajar.

Yulaelawati, Ella. 2007. Kurikulum Dan Pembelajaran Filosofi Teori Aplikasi. Jakarta : Pakar Raya. 